\title{
Andreas Predöhl's Theory of the Integration of Economic and Political Space
}

\author{
Tadahisa Mizuno ${ }^{1}$ \\ ${ }^{1}$ Graduate School of Economics, Waseda University, Tokyo, Japan \\ Correspondence: Tadahisa Mizuno, Graduate School of Economics, Waseda University 177-0045, Tokyo-to, \\ Nerima-ku, Shakujiidai, 6-13-23, Japan. Tel: 3-3978-5523 or 81-3-3978-5523. E-mail: \\ mizuno-t@kkf.biglobe.ne.jp
}

Received: December 10, 2014

Accepted: December 26, 2014

Online Published: February 25, 2015

doi:10.5539/ijef.v7n3p57

URL: http://dx.doi.org/10.5539/ijef.v7n3p57

\begin{abstract}
This paper considers Andreas Predöhl's theory, arguing that it applied to both the Nazi project and post-war European integration. Predöhl maintained that tension arises from a difference between economic and political spaces when economic space transcends national borders. After the Industrial Revolution, Predöhl saw concentric world economic poles emerging successively in Europe, the United States, and the Soviet Union. There were two ways to reconstruct the European pole: the Nazi project and European integration. Predöhl's idea that political and economic space should be harmonised is worth reconsidering amid present economic challenges.
\end{abstract}

Keywords: Andreas Predöhl, economic integration, large-space economy, location theory, economic geography

\section{Introduction}

Concerning the Nazis' large-space economy (Grossraumwirtschaft) and European integration, many discussions have been held separately and independently on various aspects of economy, politics, culture, and other topics. Although such discussions have been rare, there are some aspects of continuity and commonality between the Nazis' large-space economy and European integration.

Some economists have argued that Friedrich List (1789-1846) influenced the Nazis' large-space economy project, and others have argued that List had an influence on the European Union (EU) (Akamatu, 1965, pp. 189-193; Itagaki, 1964, p. 14). In the ninth chapter of his book, The New Economic Order and European Economic Integration, Keith Tribe also pointed out that movements seeking new economic orders oversaw both the Nazis' large-space project and the European Union and that both movements had the same roots and motivations for economic orders (Tribe, 1995, p. 260).

Even though such continuities between the two movements have sometimes been seen in economic, political, social, and cultural histories, they have rarely been discussed in economics. However, these two periods cannot be treated separately when considering a German economist who was engaged in the Nazis' large-space economy project and in discussions on European integration, namely the European Economic Community (EEC) developing to the EU. The theory of Andreas Predöhl (1893-1974) (Note 1) was relevant to the Nazis' large-space economy project but could apply also to European integration after World War II. For Predöhl, the Nazis' large-space economy project was based on military force, and post-war European integration was founded on a shared vision of federation. The key concept uniting these two different regimes, before and after World War II, consisted of an economic space that was constructed according to economic activities and oriented around central markets in core areas in von Thünen's Rings as well as a political space (i.e., national territories) that was constructed based on other principles and supported the autonomy of nations. Predöhl's original thought was to use two spaces, economic space and political space.

Predöhl's concept of the world economy is different from that of his teacher, Bernhard Harms (1876-1939), whose world economy consists of the universal and pure economic space but includes no political factors (Harms, 1912, 1913). In contrast, Predöhl's world economy consists of two spaces, economic and political. Economic space is integrated into regions and continents, and world trade is executed within this space. Moreover, Predöhl's economic space transcends political space. 
This paper intends to clarify the theory of Predöhl and demonstrate that is applicable to both periods, before and after World War II, even under quite different regimes. His theory concentrates on the tension that lies between economic space and political space. He deals correctly with the relationship between economy and politics, which is often ignored. Predöhl is generally recognised only as a theorist famous for the substitution principle in the field of economic geography and separately as the Nazis' economist. In order to form a complete view, his thoughts should be integrated as a whole.

In Section 2, I will consider the work that influenced Predöhl's thoughts. His theory of economic concentrations within the world economy will be examined in Section 3. In Section 4, I will discuss his theory to resolve tensions between economic space and political space in Europe. As noted in my conclusion in Section 5, Predöhl's theory of space is a vision of the world economy based on location theory. To resolve the tensions between economic space and political space, the only option is for political space to accept or compromise with economic space.

\section{The Works Influencing Predöhl}

The name Predöhl was famous for the substitution principle of his early work, which is still quoted in economic geography today. In Germany, Gerhard Stavenhagen, reserved some pages for Predöhl in his Geschichte der Wirtschaftstheorie (History of Economic Theories). However, as Predöhl was close to the Nazi government at the time of World War II and was accused by some Nazi economists of not accepting anti-international division of labour theory, his name was only occasionally mentioned and his theory was rarely discussed. Only F. Eulenburg (1867-1943) mentioned his location theory, criticising Predöhl for focusing on production and not caring about consumers (Eulenburg, 1932). After World War II, Predöhl was recognised as an economist who had sympathised with the Nazis. Aside from his substitution theory, his theory of a world economy based on locations was largely ignored. However, his successor H. Jürgensenn (1924-2008), who worked as a transportation economist, and Alfons Lemper (1934-2013), Predöhl's last pupil, taught location theory at Bremen University.

In Japan, Predöhl's name is rarely used. Only N. Morimoto had tried to discuss his theory however, he did not accept his work after World War II, and H. Yakushiji mentioned his theory as foreign trade theory (Yakusiji, 2008). The first reason for his lack of renown is that he is recognised as economic geographer, not an economist. His name is not well known within economics. The second reason is his position in the Nazi regime. However, Predöhl's name remains well known in Germany among older-generation economists. His articles and books are quoted still today, although in a limited field. After World War II, he remained a professor at Kiel University and was later promoted to Principal of Münster University (1959-1962). He also worked as an expert on European integration and a transportation economist.

Predöhl's theory was mainly influenced by three economists: von Thünen, who proposed the location theory of agriculture and was famous for von Thünen's Rings, Alfred Weber, who built industrial location theory on von Thünen's theory, and Josef Schumpeter, known for his theory of economic development. Predöhl himself proposed the substitution principle as combining economic theory (price theory) with Weber's industrial location theory. As such, this section will consider each of these influential thinkers in turn.

\subsection{Von Thünen's Isolated State}

One concept related to the isolated state is the so-called von Thünen's Rings model. This important concept in economic development is still used today. Under this idea, all work except agriculture is concentrated in a central city of the isolated state. Assuming land fertility is the same throughout the state, transportation costs increase with the distance from the central market, and productivity falls. As a result, agricultural products and agricultural methods are clearly sorted in concentric circles.

The outer-most circle (the sixth ring) is uninhabited wilderness: the frontier of the state. Due to expensive transportation costs, the distance to the centre constitutes a barrier to extending cultivation into this zone. When it is connected by a railway with the centre, products can be supplied to the city with lower transportation costs, agricultural areas expand, and the state becomes larger. The development of railways is the main reason for the expansion of economic space in von Thünen's isolated state (Von Thünen, 1875, pp. 104-107). The concentric circles vary according to economic development. The model of rings with differential rents forms the beginnings of discussions of location theory and is a fundamental basis for it. Moreover, Predöhl's theory is basically constructed by applying von Thünen's Rings to the European continent.

\subsection{Weber's Industrial Location Theory}

Alfred Weber wrote in Ueber den Standort der Industrien (On the Location of Industries) that transportation and 
labour costs have fundamental influences on industrial locations (Weber, 1922, p. 123). Areas of agglomeration have advantages due to product concentration, with a cost-minimising effect on production and sales; examples of these include facilities enlargements, labour organisations, and major transactions (Weber, 1922, pp. 124-127). Weber theoretically discussed industrialisation using location diagrams (Standortsfiguren) and weight diagrams (Gewichtsfiguren) (Weber, 1922, pp. 50-61). He proposed three types of industrial locations: consumption-oriented, material-oriented, and labour-oriented locations.

Two years later, Weber wrote the article 'Standortslehre und die Handelspolitik' (Location Theory and Trade Policy). In it, he argued that industrial locations are oriented towards either materials or labour supply and that the industrial location of Germany was very favourable because coalfields and labour markets were nearby. His arguments were developed further in the paper 'Europa als Weltindustriezentrum und die Idee der Zollunion' (Europe as the World Centre of Industries and the Idea of the Customer Union) in 1926. He proposed an idea of 'Konfederation der Produktionskräfte' (the Federation of Productive Powers), modelled after List's custom union. In this paper, he expanded the economic space from nation-states to the European continent. He explained that, under his idea, companies would seek optimal locations on the European continent independently of national borders based on the three types of industrial locations; the union would levy customs against another continent, namely North America.

Weber extended location theory from agriculture to industry and analysed optimal production locations. In his conception, optimal production locations transcend national borders and economic space extends over political space (national territories). We can say that his idea was realised after World War II in the European Coal and Steel Community (ECSC). Predöhl, too, was greatly influenced by Weber's proposal.

\subsection{Predöhl's Substitution Principle}

However, the theories of von Thünen and Weber mentioned above differ from standard economic theories because they include locational concepts. Predöhl, in turn, thought that both the statistical aspect of economic price theory and the dynamic aspect of location theory were needed to understand economic development and that location theory's 'places' could be used in economic theory. He felt the two types of theories could and should be bound together (Predöhl, 1925, 1928).

He thus introduced the so-called substitution principle, formed from Gustav Cassel's (1866-1945) Knapfheitsprinzip (tight principle) (Cassel, 1927). G. Stavenhagen included a section on Predöhl's substitution principle in the fifteenth chapter, 'Die Raumwirtschaftslehre', of his book, noting that Predöhl combined location theory with economic theory in his substitution principle (Stavenhagen, 1969, pp. 474-476). When we recognise production as a matter of technique selection, this entails a substitutionary relationship between rent and transportation costs (namely capital and labour), as in the case of von Thünen's model. This can also be applied to the relationship between weight and transportation cost and then labour costs, as in the case of Weber. Accordingly, the problem of location can generally be included within economic theory.

\subsection{The Concept of Development}

Predöhl's thoughts on economic development, a main part of his theory, come from Schumpeter's concept of economic development. Namely, the development mechanism arises from innovations in the static circulation of an economy. Predöhl accepted Schumpeter's vision, making the innovations accelerated by new transportation systems. Predöhl depicted his concept of economic space using von Thünen's Rings, enlarged according to economic development via Weber's economic agglomerations. Economic development increases and the rings expand as time progresses. Transaction densities become thicker, and economic activities expand across national borders. Predöhl praised Schumpeter, saying that his development theory did not rely on mathematics and had a stronger relationship to historical time. Predöhl presented a similar view via his 'polarisation of the world economy' concept in his book Aussenwirtschaft.

\section{Predöhl's Integration Theory}

\subsection{Economic Space and Political Space}

Predöhl argued in his 1934 thesis that industries were built on agricultural lands according to Weber's industrial location theory and that agricultural areas moved to the periphery in accordance with industrial development and the resources located in the frontiers outside the peripheries. He insisted that concentric rings formed in core-periphery-frontier relationships, much like von Thünen's Rings (Von Thünen, 1875). Economic spaces grew larger and larger as economic development progressed and the rings stretched outwards. These economic spaces combined together with other economic spaces to form even larger economic spaces. He called these movements 'the magnification of economic space'. Economic space transcended national borders subject to economic 
development.

Looking back 100 years, Predöhl stated that Germany was able to form the economic foundation for economic integration by accomplishing the customs union of 1834 (Note 2). The political space also achieved political integration with the establishment of the German Empire in 1871 and then pursued expansion of economic space. The world economy expanded mainly through the agglomerations of industries, namely the heavy industries that were oriented around important regional resources, particularly coalfields, and were accumulating in short-range sales zones. For examples, such industries were clustered in Belgium, northern France, the Ruhr region of western Germany, central England, and Pittsburgh and Chicago in the United States. Agriculture was concentrated in the peripheries, near the core industrial areas. England, western Germany, the Netherlands and Denmark formed the industrial and intensive agricultural core areas, thus making up the central ring. Around the core areas were located peripheries of agriculture, and even further-out areas were frontier zones, including overseas resources (Predöhl, 1934, pp. 3-4). Economic space extended over national borders, and the von Thünen's Rings extended to cover the European continent.

However, economic space in Europe is usually divided by national borders. For example, industrial areas in some countries extend across national territories, like the iron and steel industries in Alsace-Lorraine and Saarland in Germany, France and Belgium. Predöhl insisted that the tensions and conflicts arose from the discrepancy between economic space and national territories as economic space expanded. These tensions were expressed in foreign trade policies. The reason for this was that the political space necessitated foreign trade policies to control and regulate the economic space.

When we consider only economic space, Predöhl's thoughts resemble recent neo-liberalism, and he laid autonomous economic development at its basis. His conception, however, was that economic policies emerged from the political space as realisations of national political needs and were not motivated by an idea of laissez-faire. He considered the relationship between political space and economic space. He thought that the economy had a universal tendency towards autonomous development independent of a nation's will but that economic policies came out from a political space, which tried to realise the nation's will. His vision was thus different from laissez-faire. Economic space develops itself according to the principle of the economy as universal nature. However, the intentions emerging from political space work to create economic policies. There is no way to resolve such tensions between economic space and political space except by balancing the two spaces (Predöhl, 1934, p. 6).

These tensions became more noticeable during the stagnant phase of the world economy, reflected in the situation at the time, the 1930s. As economic space expanded larger and larger, it became more and more difficult to make it congruent with national territories. This meant that national territories were bounded by their particular von Thünen's Rings, especially in Europe. This period corresponded with the structural change in capitalism from free competition to a controlled and managed economy.

Predöhl argued that retaining a nation's independence during the recession phase induced the nationalisation of the economy and required autarky (self-efficiency) policies. As autarky principally restricted the economy to be within a national territory, economic efficiency was reduced; this inefficiency then became the people's burden, because this behaviour was meant to disappear amidst optimal international division of labour. However, as far as the people were willing to bear such a burden, autarky would be temporarily possible. Nevertheless, if it continued, it would cause large inefficiencies and the collapse of nations. A balance thus needed to exist between the minimum level that populations were willing to bear and the optimum level of the international division of labour. This means that nationalisation-seeking autarky is difficult to achieve without international trade. The goals were inconsistent with one another but necessary to harmonise. Predöhl concluded that the economic nationalisation movement should provide for international trade (Predöhl, 1934, pp. 10-11).

His understanding was unchanged in his thesis of 1940, 'die Sogenannten Handelshemmnisse und der Neuaufbau der Weltwirtschaft' (The so-Called Trade Hindrance and New Construction of the World Economy; Predöhl, 1940), but Germany had been at war since the previous year. One would expect Predöhl to take a realistic stance, because he belonged to der Gesellschaft für Europäische Wirtschaftsplannung und Grossraumwirtschaft (Note 3) as one of its key members.

Predöhl desired international trade, but the actual political situation was already tending towards blocked economies; he thus accepted a space enlargement with allied nations and a managed economy within a larger space as a second-best choice. He was also engaged in the international settlements system, because he was responsible for foreign trade in the Nazi regime. Indeed, he was a representative of Germany at the meeting of the Committee of Inquiry for Economic Peace of the International Chamber of Commerce in Paris in 1939 
(Trepp, 1977, pp. 75-6; Predöhl, 1949, p. 298).

Predöhl's conception seemed similar to the large-space economy of the Nazis, which required autarky according to the new European order that was presented in a radio announcement by Reich minister Funk in July 1940. Funk described a new European order based on a large-space economy, which intended to establish a Nazi regime all over the European continent. For example, Predöhl's concept of peripheries with agriculture was similar to the Nazis' vision of the eastern agricultural areas. The Nazi project, however, was based on the party's own ideology of reorganisation of inhabitants due to racism and the forced reallocation of industries and resources by the Reich. Predöhl's thoughts, as described above, were based on the rational and autonomic principle of allocation, which was different from the lebensraum of the Nazis. The Nazis' lebensraum arose from geopolitics and racism, as seen in the Nazis' slogan 'blood and ground'.

However, Predöhl's position in the Nazi regime has been criticised in recent studies. Although he suggested acceptance of the regime at the beginning of his 1934 thesis, he remained consistent in his thoughts as an economist and circumspect about the regime's military aspect, for example the invasion of USSR (the union of Soviet Social Republic) in 1941 (Predöhl, 1934, p. 12). He did not accommodate his ideas based on the will of the government (Bruckschwaiger 1999, p. 209). The Nazis' large-space economy (Grossraumwirtschaft) was different from Predöhl's large economic space (Grosswirtschaftsraum), and his theory could be applied to European integration after World War II. The reason is quite simple: his contribution to thought was merely to recognise the tension between economic space and political space, an idea that was also applicable to the post-war world.

Even though the collapse of the Third Reich was a highly salient event, it meant only the change of the political space or political regime. Predöhl did not need to change his theory. His fundamental view retained its consistency and continuity. There was merely a change of tensions and policies emerging from the political space while the economic space remained unchanged.

\subsection{Aussenwirtschaft (World Economy) as Predöhl's Theoretical System}

Predöhl kept his position as a professor at Kiel University, published his masterpiece Aussenwirtschaft (World Economy) in 1949 and completed his theory in the years after the end of the war. Aussenwirtschaft appeared amidst the confusion between World War II and the Cold War. In this book, Predöhl structured his theory as a concept of concentric poles in the world economy. The book has about 400 pages and consists of three parts. The first part presents his integration theory, the second, titled 'Political Space and Economic Space', discusses his trade policy, and the third takes up currency policies under the title 'International Trade'. The main theoretical part is the first part; the second and third parts are applications of his theory.

In Aussenwirtschaft, the concept of tensions between economic space and political space was shown to have improved from its pre-World War II state due to economic development. Both spaces expanded from isolated states to land-states (Territorien) and then to nation-states. Political space finished as nation-states, but economic space further expanded to the scale of the European continent; economic space covered all of Europe.

The book offered a conception of the world economy as having a concentric pole; the time dimension of historical development was introduced via evolutionary and expansive aspects, and Predöhl's theoretical system was enlarged to three dimensions: two planar dimensions and the added dimension of 'time' (Note 4). Before World War II, Predöhl had no recognition of historical developments and lacked a global view. He could only discuss the relations between Germany and the continental countries. After the war, he introduced historical and global aspects into his theory from the viewpoint of the development of capitalism and systematically improved his theory. It was a major improvement, but his fundamental vision of the integration of Europe stayed along the same line as it had been before the war.

The development of the world economy was accompanied by improvements in transportation technologies; ships to railways, railways to cars, and inclusion of airways and information networks (telephone and telegraph) (Predöhl, 1958). The application of the theory was expanded from two dimensions (planes) to three dimensions, including a historical dimension. With this improvement, Predöhl could build a cubic structure for his theory and widen his vision from Europe to the world. As such, we will examine his book's concept of 'the world economy with concentric poles' in the following sections.

\subsubsection{The Uni-Concentric World Economy}

Predöhl's economic space envisioned economic development activities as being oriented towards core consumption centres according to the profit maximisation principle; these movements would expand across national borders to construct a world economy in Europe. Like von Thünen's Rings, the economic space of 
Predöhl formed core-periphery-frontier rings. There were small cores in peripheries and frontiers, too, but the major streams of production transforming materials into products fundamentally flowed to core areas. The core-areas had strong powers to attract those production streams. Each factory, as a demander, received input materials from the outer areas and delivered output goods to inner areas as a supplier. The accumulations of these production movements shaped a concentric pole for the world economy, like the magnetic movements towards the earth's north and south poles. These movements were the streams of production running towards the final consumption locations. While von Thünen's Rings expressed a static economic space, Predöhl proposed the world economy with a concentric pole as being a dynamic economic space. These streams, flowing to a pole, first emerged in Europe and then formed the world economy (Note 5).

The innovations precipitating this were concentrated mainly at the time of the Industrial Revolution. Weaving machines and steam engines appeared as key innovations in the United Kingdom. Predöhl argued that the Industrial Revolution had enriched the United Kingdom; commodities produced by mass production were supplied not only to British colonies but also all over the world by the English fleet. This trade was practiced actively not only in the British Empire and in continental Europe. These movements became worldwide trade, and trade with continental countries grew rapidly. Predöhl considered this the beginning of the world economy.

The economic space in the United Kingdom and continental Europe shaped a global economy. Light industries in the first stage of the Industrial Revolution, like textiles, were ubiquitous industries, and they did not form industrial accumulations. However, the iron and steel industries drew machinery into themselves and became increasingly grouped in denser agglomerations (Predöhl, 1971, pp. 114-117). Streams of food supplies, raw materials, and half-finished and finished goods flowed into the core areas. From the cores, finished goods were exported to the peripheries, frontiers, and all over the world. This process increased the agglomeration of industries in core areas and pushed agriculture to peripheries. The von Thünen's Rings thus expanded (Predöhl, 1949, pp. 51-52).

The economic space that enlarged from the United Kingdom to the European continent formed a core area including Germany, France, Belgium, and the United Kingdom. All productive activities were concentrated towards this core, products were exported from the core to the world, and the world economy was completed. Predöhl called this period 'the integration of the world economy'. It lasted until the latter half of the 19th century.

\subsubsection{The Bi-Concentric World Economy}

As economic development proceeded further, it began shaping the second concentric pole of the world economy. The continent of North America was as large as Europe and was blessed with natural resources and raw materials such as iron, copper, gold, silver, lead, and phosphorus. This area developed rapidly, supported by the manpower provided by immigration from Europe. Large von Thünen's Rings were built on North America and shaped the second pole of the world economy (Note 6).

The centripetal force worked towards both poles (Note 7). Agricultural and industrial inputs flowed to both poles from all over the world, and finished products were exported from both poles to the entire world. World trade was performed between both areas, and the world economy progressed steadily and powerfully. Predöhl called this period 'the expansion of the world economy'. This expansion continued after the end of World War I, supported by the development of transportation and communication tools. Concentration was strengthened and accelerated by the diffusion of the technologies of the Industrial Revolution and by transportation mechanisms, including seaways and railways (Predöhl, 1949, p. 69). The world economy moved forward powerfully, and world trade accelerated around the bi-concentric poles of the world economy.

\subsubsection{The Tri-Concentric World Economy}

However, this positive trend of one-way expanding world markets was choked when frontier regions were reclaimed and the need for additional labour was satisfied. The period of expansion ended. Then economic slumps became noticeable and spread across national borders. The recessions were magnified to involve several countries simultaneously (Predöhl, 1949, pp. 93, 101-103). The time of free competition was gone, and economic activities were soon strikingly marked by monopolies and oligopolies aiming to retain high profit shares.

As a result of free trade, the world economy was increasingly involved in business cycles. At the beginning of the twentieth century, emigration to the new continents compensated and buffered such recessions. When these buffers did not work, however, slumps and recessions directly affected the world economy. The economy lost its order, and problems of bankruptcy and unemployment came to the fore. Instead of the balanced exchange rates 
arising from a flexible price system, each country controlled their exchange rates and foreign trade. Because every nation suffered from unemployment within its own population, economic policies were designed to encourage full employment.

World trade thus became restricted. The energy for developing the world economy lost its direction. Every nation within 'the world economy with concentric poles' sought to deepen the economy within its national borders and changed direction to promote intensification of the domestic economy. Trade policies turned protective to safeguard each national economy. World trade policies increased in importance and changed focus from free trade to bilateral treaties or 'most favoured nation' clauses. Governments' currency policies strengthened controls on exchange rates. As a result, economic policies became restrictive in order to secure the national economy, and the economy was forced to remain within national borders. Each government sought to find an economic optimum within its own territories. Predöhl called this the tendency to autarky (Predöhl, 1949, p. 164).

At that time, the gold standard system reached its limit. Predöhl stated that it was inevitable that the national economy would be maintained, even though the world economy became circumscribed. He named this period 'the intensification of the world economy'. The world economy collapsed in the economic panic of 1929, at which time all economic indexes turned negative (Note 8). Thus, the world economy had reached the end of its expansion, and the first 'world economic pole' was declining and breaking down. In this difficult context, the Soviet Union was able to establish a third concentric pole of the world economy by means of the complete control and management of the planned economy with reckless deforestation and trial and error (Predöhl, 1949, p. 115). The key word of this period was 'intensification'. However, the third concentric pole needed time to develop and was finally completed with the establishment of COMECON after World War II (Predöhl, 1971, p. 134). While the third pole was being built up through a planned economy and military power, the first European economic space was divided and separated in pieces by national borders. This was a consequence of economic policies that prioritised protecting national economies.

\section{Tensions between Economic Space and Political Space}

'The period of world economic intensification' before and after World War II was a main part of Predöhl's argument. He insisted that one way to resolve the tensions arising from the difference in the areas of economic space and political space was the Nazis' large-space economy with its military force; the other method was European integration after World War II.

Keith Tribe saw a similarity and continuity between the Nazis' regime and the integration movements in Europe after World War II; Predöhl shared this comprehension of the situation but in another aspect. Tribe wrote as follows:

'The reactions of both Guillebaud (Note 9) and of Keynes to Funk's proclamation of the New European Order in July 1940 demonstrate that a more balanced perspective upon the process of the European integration is possible. Instead of seeing the creation of the European Union as part of political settlement of post war Europe, it can be seen as a response to forces in the international economy, and thus from the general perspective of the world economic order'. (Tribe, 1995, p. 260)

Tribe's viewpoint focused on the continuity of economic order. However, Predöhl's vision was also applicable to the ECSC, according to the Schuman Plan, and aligned with the establishments of the European Economic Community (EEC) and the European Atomic Energy Community (EURATOM). These alliances were established along the same von Thünen's Rings, which extended over national territories aiming at optimal production. They had no plan to use military power, which had been used by the Nazis. This was the first step towards the mutual consensus to integrate economic space and political space across the European continent. Predöhl said that the ECSC stimulated the EEC and the EEC stimulated enlargement of the economic space. The EEC gave new motivation to efforts seeking European integration in the Marshall Plan countries. He stated that European integration would be difficult for the OEEC (the former OECD) (Predöhl, 1971, p. 243). Predöhl argued that resolving the burden of separate borders was necessary for building a large economic space covering the European continent (Note 10). Stabilisation policies required the coordination of nations. Coordination is worth adopting in industrial, currency and transportation policies, but these policies are greatly influenced by each government (political space). Predöhl insisted that European integration was necessary for furthering development of Europe and the wider world and that economic growth required not only reducing a nation's customs but also taking such policy actions uniformly by lowering all national barriers. This matter concerns an alternative judgment between independence of nations or integrations. The harmonisation is expected there. Predöhl wrote at the end of his book as follows:

'The theory of economic development teaches us how the rational economic tendency was strong against 
political counter-powers. We could forecast a positive future for European integration. This is also effective in currency integration policies. Nevertheless, the political power against integrations is not weak. For this reason, it is necessary not to confuse economic integration with political integration. Although political integration provided the premise to find economic integration, the political counter-power to retain sovereignty is made more powerfully strengthened by this sentence, "We are just expected to overcome the atavism in politics, which originated in the discrepancy between technical and economic progress in the world and in the backwardness of political organisations" (Predöhl, 1971, pp. 311-312).

Economic space has its own autonomic tendencies according to economic principles. Only the political space has the ability to coordinate these tendencies. We must thus accept this tendency through economic policies aiming to attain stabilisation. The currency problems within regions would cause conflicts if nations were individually separated (Predöhl, 1971, pp. 306-307). Predöhl proposed a wider-band floating exchange rate system instead of a pure floating exchange rate system because the currency problem directly concerned sovereignty itself and nations primarily seek to maintain independence. The wider-band system was introduced in 1979, five years after his death.

Predöhl did not live to see the establishment of the EU, but he did forecast some of the related historical events. Namely, the development of the extended EC, the establishment of the EU (1993), and the introduction of the European Monetary System (EMS) as a currency system (1979) were in line with the development that Predöhl had suggested. In this way, the first economic pole of Europe became newly active and regained economic power in the world economy.

\section{Conclusion}

This paper has re-examined the theory of Andreas Predöhl to consider the relationship between the Nazi large-space economy and European integration. The dynamic development of Predöhl's theory is characterised by geographically horizontal expansions similar to von Thünen's Rings, which are simultaneously related to historical development. Predöhl argued that this economic expansion had shaped the first world economy, based around the uni-concentric pole of Europe, starting from the Industrial Revolution. He considered this the integration period of the world economy. Later, the second concentric pole emerged in the United States during the expansion period of the bi-concentric world economy. The third concentric pole was formed in the USSR via the planned economy during the intensification period, thus forming the tri-concentric world economy.

The main discussion of this paper centred around the tri-concentric poles period. Predöhl thought that the Nazis' large-space economy stood on the same conceptual ground as European integration. They shared the same von Thünen's Rings. The difference arose only from the political space, namely the difference between the regimes. According to Predöhl's theory, the difference between before and after World War II lay in the regime change in the political space, while the economic space remained unchanged.

Although the theory of Predöhl was once used in the Nazi Reich, his theory provided the tools to understand European integration. He did not discuss its commonality with the Nazis in his book, written at the time of the Cold War. The reason why his theory remained useful even after World War II was that he recognised only the tensions between economic space and political space, and that these tensions were realised in economic policies, especially those regarding borders. He said nothing directly about political regimes. He could thus separate out the political elements that were included in German political economics or other national economic policies and place all these non-economic elements into the political space. After doing this, it was possible to apply economic theory to any situations, indifferent of the political regimes. However, Predöhl did not ignore the political elements. He treated them in the form of economic policies, expressing tensions between economic space and political space.

Predöhl argued that national sovereignties need not be denied, but he expected nations to reduce their rights, to the extent possible, and deliver these rights to a common organisation. Only in this way could Europe achieve integration and stability. On reflection, if we remain in a state with perfect sovereignty, integration becomes unstable. Predöhl insisted that the way to stabilise and develop the world economy was through the mutual understanding of other nations (Note 11). Predöhl mainly viewed the tensions between economic space and political space within Germany and in Europe. However, his theory has universality and is applicable worldwide. It is thus worthwhile to recognise his theory once again.

\section{References}

Akamatsu, K. (1965). Sekai keizai ron. Tokyo: Kunimoto.

Bruckschwaiger, K. (1999). Carl Schmitt am Rande des Grossraums - Die kurze Geschichte des Begriffs', hrsg. 
Wolfgang Pircher, Gegen den Ausnahmezustand. Zur kritik an Carl Schmitt (pp. 201-207). Wien: Springer.

Cornelissen, C., \& Mish, C. (2009). Wissenschaft an der Grenze: die Universität Kiel im Nationalsozialismus. Essen: Klartext Verl.

Dieckmann, C. (1992). Wirtschaftsforschung für den Großraum. Beiträge zur nationalsozialistischen Gesundheits-und Sozialpolitik. Bd, 10, 124-198.

Grotewold, A. (1971). The growth of industrial core areas and patterns of world trade. Annals of the Association of American Geographers, 61(2), 361-370. http://dx.doi.org/10.1111/j.1467-8306.1971.tb00788.x

Grotewold, A. (1973). West Germany's economic growth. Annals of the Association of American Geographers, 63(3), 353-365. http://dx.doi.org/10.1111/j.1467-8306.1973.tb00933.x

Hallstein, W., Predöhl, A., \& Baade, F. (1951). Probleme des Schumann-Plans. Kiel: Institut für Weltwirtschaft an der Universität.

Harms, B. (1912). Probleme der Weltwirtschaft. Schriften des. Jena: Gustav Fischer.

Harms, B. (1913). Weltwirtschaft und Weltwirtschaftslehre. Weltwirtschaftliches Archiv, 1, 1-36.

Itagaki, Y. (1964). Europa Tougougainen no Keisei to Hatten. In Y. Itagaki \& N. Yamamoto (Eds.), Oushu Keizaitougou no Bunseki to Tennbou (pp. 1-15). Tokyo: Nihon Kokusai Monndai Kenkyujo.

Janssen, H. (2009). Nationalökonomie und Nationalsozialismus. Marburg: Metropolis.

Kappel, R. (2010). On the Economics of regional powers: Comparing China, India, Brazil, and South Africa. GIGA working paper, 145 .

Kappel, R. (2011). The challenge to Europe: Regional powers and the shifting of the global order. Intereconomics, 46(5), 275-286. http://dx.doi.org/10.1007/s10272-011-0392-5

Kappel, R., \& Brach, J. (2009). Handel, Hierarchien und Kooperation in der Globalisierung. GIGA working paper, 95 .

Lemper, A. (1998). Predöhl und Schumpeter: Ihre Bedeutung für die Erklärung der Entwicklung und der Handelsstruktur Asiens. Bremen: Institut für Weltwirtschaft und Internationales Management, Fachbereich Wirtschaftswissenschaft, Universität Bremen.

List, F. (1930). Das nationale System der politischen Ökonomie. Berlin: Reimer Hobbing.

Mackenroth, G., \& Predöhl, A. (1948). Deutschland und die wirtschaftliche Einheit Europas: Okonomisches Manifest zum Marshall-Plan. Hamburg: Auerdruck.

Morimoto, N. (1956). Sekaikeizaigaku no Kenkyu. Kyoto: Sekishoin.

Perroux, F. (1950). Economic space: theory and applications. The Quarterly Journal of Economics, 64(1), 89-104. http://dx.doi.org/10.2307/1881960

Petersen, H. (2009). Expertisen für die Praxis. In C. Cornelissen, \& C. Mish (Eds.), Wissenschaft an der Grenze (pp. 57-79). Essen: Klartext.

Predöhl, A. (1925). Das Standortsproblem in der Weltwirtschaftstheorie. Weltwirtschaftliches Archiv, 21, 294-319.

Predöhl, A. (1927). Zur Frage einer allgemeinen Standortstheorie Antikritische Bemerkungen. Zeitschriften fuer Volkswirts und Sozialpolitik, Neue Folge, 5, 757-761.

Predöhl, A. (1928a). Die örtliche Verteilung der amerikanischen Eisen-und Stahlindustrie. Weltwirtschaftliches Archiv, 239-292.

Predöhl, A. (1928b). The theory of location in its relation to general economics. The Journal of Political Economy, 371-390. http://dx.doi.org/10.1086/253950

Predöhl, A. (1934). Staatsraum und Weltwirtschaftsraum. Weltwirtschaftliches Archiv, 39, 1-12.

Predöhl, A. (1940). Die sogenannten Handelshemmnisse und der Neuaufbau der Weltwirtschaft. Weltwirtschaftliches Archiv, 52, 193-222.

Predöhl, A. (1941). Großraum, Autarkie und Weltwirtschaft, Das neue Europa (pp. 158-166). Dresden: Mainhold.

Predöhl, A. (1943). Die angelsächsischen Währungspläne und die europäische Währungsordnung. Weltwirtschaftliches Archiv, 58, 1-26. 
Predöhl, A. (1949). Aussenwirtschaft: Weltwirtschaft, Handelspolitik und Währungspolitik. Göttingen: Vandenhoeck \& Ruprecht.

Predöhl, A. (1951). Von der Standortslehre zur Raumwirtschaftslehre. Jahrbuch Für Sozialwissenschaft, 2 , 94-114.

Predöhl, A. (1958). Verkehrspolitik. Göttingen: Vandenhoeck \& Ruprecht.

Predöhl, A. (1960). Weltwirtschaft und europäische Integration. Münster Westf: Aschendorff.

Predöhl, A. (1962). Das Ende der Weltwirtskriese. Reinbeck bei Hamburg: Rowohlt.

Predöhl, A. (1971). Außenwirtschaft. völlig neubearbeitete 2. Aufl, Göttingen: Vandenhoeck \& Ruprecht.

Scheuplein, C. (2009). Wirtschaftliches Maximum, völkishces Optimum: Raumwirtschaftstheorie und -politik bei Andreas Predöhl. In H. Mädig \& W. Strubelt (Eds.), Vom dritten Reich zur Bundesrepublik: Beiträge einer Tagung zur Geschichte von Raumforschung und Raumplanung (pp. 84-106). Hnnover: ARL.

Scheuplein, C. (2010). Vertical integration and macroeconomic growth: The case of the steel industry. Erdkunde, 327-341. http://dx.doi.org/10.3112/erdkunde.2010.04.03

Sombart, W. (1924). Der moderne kapitalismus: Historisch-systematische darstellung des gesamteuropáischen wirtschaftslebens von seinen anfängen bis zur gegenwart (6th ed.). München und Leipzig: Duncker \& Humblot.

Stavenhagen, G. (1969). Geschichte der Wirtschaftstheorie (4th ed.). Göttingen: Vandenhoeck \& Ruprecht.

Thünen, J. H. (1875). Der isolierte Staat auf Landwirtschaft und National Ökonomie. In H. Schumacher- Zarhlin (Ed.). Berlin: Wiegandt, Hempel \& Paren.

Trepp, G. (1977). Bankgeschäfte mit dem Feind (3rd ed.). Zürich: Rotpunkt Verl.

Tribe, K. (1995). Strategies of economic order. Cambridge: Cambridge University Press. http://dx.doi.org/10.1017/CBO9780511551529

Volkmann, H. E. (2003). Ökonomie und Expansion. München: Oldenbourg. http://dx.doi.org/10.1524/9783486594553

Weber, A. (1922). Ueber den Standortslehre (2nd ed.). Tübingen: J.C.B. Mohr.

Weber, A. (1911). Die Standortslehre und die Handelspolitik. Archiv für Sozialwissenschaft und Sozialpolitik, 32, $667-688$

Weber, A. (1926/2003). Europa als Weltwirtschaftszentrum und die Zollunion. In H. G. Nutzinger (Ed.), Alfred-Weber-Gesamtausgabe (pp. 335-345). Marburg: Metropolis.

Yakusiji, H. (2008). Sekaikeizai no Ricchi Boueki Riron. Kyoto: Kouyoushobo.

\section{Notes}

Note 1. Predöhl was a pupil, fellow officer and successor of Bernhard Harms, who founded the Kiel Institute of World Economy. Predöhl was promoted to a professor at Kiel in 1932. As the government changed to the Nazis, Harms was forced to retire, and Predöhl took up Harms' position as head of the Institute in 1934. Predöhl tried to reconstruct a relationship with the government, and the Institute's situation was well improved. He was rector of Kiel University from 1942 to 1945. After World War II, he remained as a professor at Kiel University until 1952 and afterwards moved to Münster University. He was President of Münster University from 1959 to 1962 . He later worked at the Hamburg Oversees Institute and was chairman of the government's traffic committee. He received a Grand Cross Cordon in 1968.

Note 2. The customs union was established in 1834 and expanded to cover almost the entire German economic space.

Note 3. Predöhl was engaged in Gesellschaft für Europäische Wirtschaftsplannung und Grossraumwirtschaft e.V. (Society for European Economic Planning and Large Space Economy) and was vice chairman of its academic group. Andreas Predöhl, 1941, Grossraum, Autarkie und Weltwirtschaft, Das neue Europa, Gesellschaft für Europäische Wirtschaftsplannung und Grossraumwirtschaft e.V., Dresden: Meinhold: 158-66. And Andreas Predöhl, 1943, Die Angelsächsischen Währungspläne und die europäische Währungsordnung. Weltwirtschaftliches Archiv, 58, 1-26.

Note 4. This may have been influenced by Werner Sombart. 
Note 5. François Perroux considered a space in which centripetal power worked and called it 'a pole of development'. His concept was similar to Predöhl's.

Note 6. Predöhl maintained that economic space was an aggregate of relations of production, which were counted as internal transactions in the case of large countries but as international transactions for smaller countries. Thus it is necessary to consider together not only international transactions but also domestic transactions to define the economic space.

Note 7. Perroux has similar idea about economic space, as mentioned in footnote 5. Predöhl agreed that it was similar to his concept. Andreas Predöhl, 1951, Von der Standortslehre zur Raumwirtschaftslehre. Jahrbuch für Sozialwissenschaft, 2, 94-114.

Note 8. Predöhl accepted Schumpeter's recognition that the bottoms of the Kondratieff cycle, the Juglar cycle, and the Kitchin cycle were concurrently met in 1929 (Predöhl, 1962, pp. 21-22).

Note 9. C. W. Guillebaud belonged to the Cambridge school and edited Principles of Economics by Alfred Marshall. He found the application of Keynes theory in the economic constructions of the Nazis and wrote the book, The Economic Recovery of Germany from 1933 to the Incorporation of Austria in March 1938.

Note 10. Predöhl wrote many books concerning European Integration, including: Andreas Predöhl, 1948, Deutchland und wirtschaftliche Einheit Europas: Ökonomischer Manifest zum Marschall-Plan, Hamburg: Auerdruck. The same author with W. Hallstein and F. Baade, 1951, Probleme des Schuman Plans. Kieler Vortäge-Neue Folge, 2, 18-20, 1960, Weltwirtschaft und Europäische Integration, Münster Westf: Aschendorf, and 1962, Das Ende der Weltkreise. Reinback bei Hamburg: Rowohlt.

Note 11. As I described in the first part of this paper, Predöhl had a different vision to his teacher Harms on this point. Harms thought that the world economy was a gathering of national economies and that what transcended national economies should be delivered to international organisations. On the other hand, Predöhl thought that national borders and sovereignties should be kept at as low a level as possible and that regional central organisations should exist in each region inside each economic space. Predöhl stated that there should be limits to cultivating mutual understanding and that it would be difficult to construct a unified organisation for the entire world. He required regional integration within each continent. Bernhard Harms, 1912. Probleme der Weltwirtschaft, Jena: Gustav Fischer. And the same author, 1913, Weltwirtschaft und Weltwirtschaftslehre. Weltwirtschaftliches Archiv, 1, 1-36.

\section{Copyrights}

Copyright for this article is retained by the author(s), with first publication rights granted to the journal.

This is an open-access article distributed under the terms and conditions of the Creative Commons Attribution license (http://creativecommons.org/licenses/by/3.0/). 